\title{
Microwave assisted the short time clean synthesis of 1,3-Diketones as Building Blocks in Heterocyclic Synthesis: A Facile Synthesis and Antimicrobial Evaluation of New Dihydropyridine, 4H-Pyrane, Dihydropyridazine, Pyrimidine and Pyrazole derivatives
}

dr. mohamed ahmed abdelreheim ( $\sim$ dr.mohamedabdelreheim@gmail.com ) arish university https://orcid.org/0000-0001-8667-7562

Ibrahim Saad Abdel Hafiz arish university

Hend Saad Eldin Abdel Rady

Sinai University - El Arish Campus

Research article

Keywords: Heterocycles, Microwave irradiation, Spectral characteristics and Antimicrobial activities

Posted Date: December 19th, 2019

DOI: https://doi.org/10.21203/rs.2.19335/v1

License: (ㅇ) This work is licensed under a Creative Commons Attribution 4.0 International License. Read Full License 


\section{Abstract}

Background: According to literature survey, the compounds bearing naphthalene moiety can be used as medical preparations because of their wide spectrum of biological activity and low toxicity. In this study, a new series of azoles or azines were synthesized from the reaction of the key intermediate 1-(1hydroxynaphthalen-2-yl)-3-phenylpropane-1,3-dione $\mathbf{3}$ with a variety of electrophilic and nucleophilic reagents under a variety of mild conditions.

Results: The chemical structures of these compounds were confirmed by various spectroscopic methods such as (IR, ${ }^{1} \mathrm{H}-\mathrm{NMR},{ }^{13} \mathrm{C}$-NMR, mass spectral data and elemental analyses).

Conclusions: The prepared compounds were screened in vitro for their antimicrobial activity against some species of Gram-positive bacteria (Staphylococcus aureus and Bacillus subtilis) and Gram-negative bacteria (Escherichia coli and Pseudomonas aeuroginosa). Anti-fungal activities of the compounds were tested against yeast and mycelial fungi,Candida albicans and Aspergillus flavus. The antimicrobial activity of this series was showed either weak or moderate activities.

\section{Background}

Heterocyclic compounds containing nitrogen, sulfur and oxygen atom are found to possess a varity of biological activities. A mongst them, pyrazoles, cyanopyridines, pyrimidinethiones and pyranes or their fused ring systems are found to exhibit a wide spectrum of biological activities, including antibacterial and antifungal activities. Various biological applications have been reported for pyrazoles such as anticancer, anti-tumor, antiviral, anti-inflammatory, antifungal, analgesic, antipyretic, antimicrobial, antihistaminic, antiplatelet, antihyperglycemic, sedative, hypnotic activity [1-6], antidepressant [7], anticonvulsant [8]. Cyanopyridine derivatives have attracted considerable attention as they appeared of interest to possess anticancer [9], anti-tumor [10] and antimicrobial [11 ] activities. Pyrimidinethiones have been found to possess antitubercular [12]. Pyrane and fused $4 \mathrm{H}$-pyrane derivatives have attracted a great interest owing to their antimicrobial activity [13-15], inhibitors of influenza virus sialidases [16], mutagenic activity [17], antiviral [18] and anti-tumor [19]. Also Pyridazine ring is a nucleus of a many of drugs available in the market like cadralazine (antihypertensive), minaprine (antidepressant), hydralazine (smooth muscle relaxant), pipofezine (tricyclic antidepressant) [20,21]. So, we report here the utility of 3 in the synthesis of unique heterocycles of expected biological intrest.

\section{Results And Discution}

Organic synthesis by using microwave irradiation (MW) is a new and interesting technique and is becoming popular now. The reactions under microwave irradiation takeplace in few minutes and no solvent is required [22-25]. In continution to our research for chemistry developments [26-29], we report here the use of microwave irradiation for the synthesis of 1-(1-hydroxynaphthalen-2-yl)-3-phenylpropane-1,3-dione $\mathbf{3}$ in a quantitative yield (91\%) from the reaction of a- naphthol and ethyl benzoylacetate in the presence of zinc chloride [30,33]. Rather than the expected coumarin 4 as literature [31-32]. The structure of the latter product 3 was established on the basis of its elemental analyses and spectral data and chemical transformation. 
Thus, the infrared spectrum of compound 3 revealed absorption bands at 3365, 3061, 2924, 1720, $1639 \mathrm{~cm}^{-1}$ for hydroxyl, $\mathrm{CH}$-aromatic, $\mathrm{CH}$-aliphatic and carbonyl function groups, respectively; ${ }^{1} \mathrm{H}-\mathrm{NMR}$ spectrum of compound 3 showed the following signals at $d=4.49\left(\mathrm{~s}, 2 \mathrm{H}, \mathrm{CH}_{2}\right), 7.20-8.68(\mathrm{~m}, 11 \mathrm{H}$, aromatic $\mathrm{H}), 8.69(\mathrm{~s}$, $1 \mathrm{H}, \mathrm{OH}$ ). Also, the mass spectrum of compound $\mathbf{3}$ is in agreement with the proposed struture, its showed a molecular ion peak at $\mathrm{m} / \mathrm{z}=290\left(\mathrm{M}^{+}\right)$in agreement with its molecular formula $\mathrm{C}_{19} \mathrm{H}_{14} \mathrm{O}_{3}$ [33].

The active methylene group in compound $\mathbf{3}$ was exploited to synthesize some novel heterocyclic compounds by its reaction with some electophilic and nucleophilic reagents. Thus, condensation of $\mathbf{3}$ with dimethylformamide-dimethylacetal (DMF-DMA) in dioxane afforded the enaminone derivative $\mathbf{5}$ in good yield as demonstrated in (scheme 2). Establishing the structure $\mathbf{5}$ was based on its elemental analyses and spectral data. Thus, ${ }^{1} \mathrm{H}-\mathrm{NMR}$ spectrum of compound $\mathbf{5}$ showed the following signals, a singlet signal at $\mathrm{d}=$ $3.00 \mathrm{ppm}$ assigned to $\mathrm{N}\left(\mathrm{CH}_{3}\right)_{2}$, a singlet signal at $\mathrm{d}=7.19 \mathrm{ppm}$ assigned to oliffinic proton, a multiplet signal at $d=7.64-8.67 \mathrm{ppm}$ assigned to aromatic protons and asinglet signal at $d=8.68 \mathrm{ppm}$ assigned to hydroxyl group. Moreover, the mass spectrum revealed a molecular ion peak at $\mathrm{m} / \mathrm{z}=345\left(\mathrm{M}^{+}\right)$related to molecular formula $\mathrm{C}_{22} \mathrm{H}_{19} \mathrm{NO}_{3}$. Also, when compound 3 was alkylated with triethylorthoformate in refluxing acetic anhydride afforded the ethoxymethylene derivative $\mathbf{6}$. Establishing of the structure $\mathbf{6}$ was based on spectral data in addition of elemental analyses. So, its ${ }^{1} \mathrm{H}-\mathrm{NMR}$ spectrum in DMSO- $\mathrm{d}_{6}$ revealed the following signals at $\mathrm{d}=1.11\left(\mathrm{t}, 3 \mathrm{H}, \mathrm{CH}_{3}\right), 4.19\left(\mathrm{q}, 2 \mathrm{H}, \mathrm{CH}_{2}\right), 6.33(\mathrm{~s}, 1 \mathrm{H}, \mathrm{CH}$-oliffinic), 7.29-8.23 $(\mathrm{m}, 11 \mathrm{H}$, aromatic $\mathrm{H})$, $8.68(\mathrm{~s}, 1 \mathrm{H}, \mathrm{OH})$. The mass spectrum of the same product is in accordance with the proposed structure. Thus, it showed a molecular ion peak at $346\left(\mathrm{M}^{+}\right)$.

Compound 5 readily reacted with cyanothioacetamide as example of active methylene reagents in refluxing ethanolic sodium ethoxide yield the expected pyridinethione derivative 10 which established on its spectral data ( ${ }^{1} \mathrm{H}-\mathrm{NMR}$, mass spectra and elemental analyses). So, its mass spectrum revealed a molecular ion peak at $\mathrm{m} / \mathrm{z}=384\left(\mathrm{M}^{+}+2\right)$ corresponding to molecular formula $\mathrm{C}_{23} \mathrm{H}_{14} \mathrm{~N}_{2} \mathrm{O}_{2} \mathrm{~S}$. Formation of pyridinethione 10 is believed to be proceed via initial addition of active methylene moiety in cyanothioacetamide on the $\pi$ - bond system of carbonyl group of $\mathbf{5}$ to afford the Michael adduct $\mathbf{8}$ that cyclizes by losing water under the same reaction condition to give intermediate 9 which eliminate dimethylamine molecule to yield the final structure 10 as demonstrated in (scheme 2) [34]. Furthermore, the behavior of enaminone 5 toward binucleophilic reagents was also investigated. Thus, when $\mathbf{5}$ is allowed to react with hydrazine hydrate a compound with a molecular formula $\mathrm{C}_{20} \mathrm{H}_{14} \mathrm{~N}_{2} \mathrm{O}_{2}=314\left(\mathrm{M}^{+}\right)$is formed which may be formulated as structure 14 based on spectroscopic data. Thus ${ }^{1} \mathrm{H}$-NMR spectrum of compound $\mathbf{1 4}$ showed a singlet signal at $\mathrm{d}=7.22$ assigned to pyrazole- $\mathrm{H}$, a multiplet signals at $\mathrm{d}=7.31-8.71$ assigned for $\mathrm{CH}$ aromatic and $\mathrm{NH}$ proton and a singlet signal at $d=8.73$ assigned to $\mathrm{OH}$ group. On the other hand, compound 6 was reacted with hydrazine hydrate to afford the product identical in all respects ( $\mathrm{mp}$, mixed $\mathrm{mp}$, and spectral data) with those corresponding to the pyrazole derivative $\mathbf{1 4}$ as demonstrated in (scheme 2).

Similarly, reactions of enaminone $\mathbf{5}$ with urea or thiourea to yield the expected pyrimidine derivatives $\mathbf{1 6 a , b}$. Compounds 16 a,b were established on its correct spectral data (IR, ${ }^{1} \mathrm{H}-\mathrm{NMR}$, mass spectra and elemental analyses). Also, enaminone $\mathbf{5}$ reacted with guanidine hydrochloride to yield the pyrimidine derivative $\mathbf{1 8}$ which established on spectral data. On the other hand, reaction of enaminone $\mathbf{5}$ with hydroxylamine 
hydrochloride in ethanol containing anhydrous sodium acetate afforded the isoxazole derivative 20 .

Structure $\mathbf{2 0}$ was established based on its elemental analyses and spectroscopic data. Thus, the ${ }^{1} \mathrm{H}-\mathrm{NMR}$ of 20 revealed the presence of a singlet signal at $d=7.21 \mathrm{ppm}$ corresponding to the isoxazole proton and a multiplet signal at $d=7.31-8.70 \mathrm{ppm}$ corresponding to aromatic protons and asinglet signal at $8.71 \mathrm{ppm}$ corresponding to $\mathrm{OH}$ group. The mass spectrum of compound $\mathbf{2 0}$ is revealed a molecular ion peak at $\mathrm{m} / \mathrm{z}=$ $315\left(\mathrm{M}^{+}\right)$corresponding to the molecular formula $\mathrm{C}_{20} \mathrm{H}_{13} \mathrm{NO}_{3}$ as demonstrated in (scheme 3).

3-phenylpropane-1,3-dione derivative $\mathbf{3}$ was examined as a key precursor toward a variety of nucleophlic and electrophilic reagents aiming at exploring its synthetic potentiality. Thus, when compound $\mathbf{3}$ was reacted with hydroxyl amine hydrochloride to yield the isoxazole derivative $\mathbf{2 3}$ in good yield. Compound $\mathbf{2 3}$ was established based on its spectral data (IR, ${ }^{1} \mathrm{H}-\mathrm{NMR}$, mass spectra) and elemental analyses. ${ }^{1} \mathrm{H}-\mathrm{NMR}$ of the compound 23 showed a singlet signal $d=7.21 \mathrm{ppm}$ assigned to $\mathrm{CH}$-isoxazole, a singlet signal at $d=8.69$ ppm assigned to $\mathrm{OH}$ group beside the multiplet signal at $d=7.32-8.54 \mathrm{ppm}$ assigned to aromatic protons. The mass spectrum showed a molecular ion peak at $\mathrm{m} / \mathrm{z}=287\left(\mathrm{M}^{+}\right)$corresponding to molecular formula $\mathrm{C}_{19} \mathrm{H}_{13} \mathrm{NO}_{2}$ as demonstrated in (scheme 4).

The reactivity of compound $\mathbf{3}$ toward active methylene reagents was also investigated and found to afford new pyridinone derivative. Thus, when compound $\mathbf{3}$ was reacted with malononitrile in ethanolic sodium ethoxide, a product 26 with molecular formula $\mathrm{C}_{22} \mathrm{H}_{14} \mathrm{~N}_{2} \mathrm{O}_{2}$ was obtained as the sole isolable product through the intermediates $\mathbf{2 4}$ and $\mathbf{2 5}$ [35]. On the other hand, reactions of $\mathbf{3}$ with a mixture of malononitrile and elemental sulfur in ethanolic piperidine afforded the expected thiophene derivative $\mathbf{2 9}$ as demonstrated in (scheme 5) [34]. Assignment of structure 29 for the reaction product was based on its correct elemental analyses and compatible spectroscopic data, ${ }^{1} \mathrm{H}$-NMR of the structure revealed a singlet signal at $\mathrm{d}=8.69$ ppm corresponding to $\mathrm{OH}$ group beside the multiplet signals corresponding to the aromatic protons and $\mathrm{NH}_{2}$ at $d=7.20-8.68 \mathrm{ppm}$. Also, the mass spectrum showed a molecular ion peak at $\mathrm{m} / \mathrm{z}=370\left(\mathrm{M}^{+}\right)$ corresponding to the molecular formula $\mathrm{C}_{22} \mathrm{H}_{14} \mathrm{~N}_{2} \mathrm{O}_{2} \mathrm{~S}$.

One-pot reaction of a mixture of compound $\mathbf{3 1}$ and dimedone in the presence of ammonium acetate afforded the tetrahydroquinoline derivatives $35 a-c$. Assignment of structure $35 b$ as example for the reaction product was based on its compatible spectroscopic data. Thus, its IR spectrum showed absorption bands at $3371,3255 \mathrm{~cm}^{-1}$ for $(\mathrm{OH} / \mathrm{NH}), 3059 \mathrm{~cm}^{-1}$ for (CH-arom), 2954-2835 cm-1 for (CH-aliph) and 1639, $1620 \mathrm{~cm}^{-1}$ for $(2 \mathrm{C}=0)$ group. However, the ${ }^{1} \mathrm{H}-\mathrm{NMR}$ of compound $\mathbf{3 5} \mathrm{b}$ for example showed a singlet signals at $\mathrm{d}=0.82$, $1.19 \mathrm{ppm}$ corresponding to $2 \mathrm{CH}_{3}$, two singlet signals at $d=2.70 \mathrm{ppm}$ and at $\mathrm{d}=2.86 \mathrm{ppm}$ corresponding to two methylene groups of dimedone, a singlet signal at $\mathrm{d}=3.70 \mathrm{ppm}$ assigned to $\mathrm{OCH}_{3}$ protons, a singlet signal at $\mathrm{d}=4.49 \mathrm{ppm}$ assigned to $\mathrm{CH}$ - pyridine, a singlet signal at $\mathrm{d}=8.45 \mathrm{ppm}$ assigned to $\mathrm{OH}$ group beside the multiplet signals at $d=7.21-8.28 \mathrm{ppm}$ assigned to aromatic protons and $\mathrm{NH}$. The mass spectrum of the same compound revealed a molecular ion peak at $529\left(\mathrm{M}^{+}\right)$and a number of fragments which agree with the proposed structure. The formation of $35 \mathrm{a}-\mathrm{c}$ can be understood in terms of the Michael type addition of the active methylene group in the dimedone molecule to the activated double bond in the compound $\mathbf{3 1}$ to yield the Michael adduct $\mathbf{3} \mathbf{3}$ and cyclized to $\mathbf{3 4}$, the intermediate $\mathbf{3 4}$ was oxidized by loss of water to yield the final product 35 [ 36-38] as demonstrated in (scheme 6). 
Reactions of compound $\mathbf{3}$ with some electrophilic reagents under alkaline conditions were also investigated. Thus, $4 \mathrm{H}$-pyran-3-carbonitrile $\mathbf{4 0 a , b}$ were synthesized in an excellent yield upon treatment of $\mathbf{3}$ with arylidinemalononitrile $\mathbf{3 6} \mathbf{a}-\mathbf{b}$ in the presence of a catalytic amount of piperidine. The structures of compounds $\mathbf{4 0 a , b}$ were established based on analytical and spectral data. Products $\mathbf{4 0 a , b}$ are apparently formed via a Michael type addition of the active methylene group in compound $\mathbf{3}$ to the activated double bond in arylidinemalononitrile $\mathbf{3 6} \mathbf{a}, \mathbf{b}$ to form the non-isolable intermediate $\mathbf{3 9}$ through an intramolecular cyclization and subsequent tautomerization to give $\mathbf{4 0 a , b}$. Also, compound $\mathbf{3}$ was reacted with arylidinecyanothioacetamide to yield the acceptable pyridinethione derivatives $45 \mathrm{a}-\mathrm{c}$. We first assumed that the reaction product is formed via addition of active methylene to a, $\beta$-unsaturated linkage and subsequent water elimination from carbonyl benzoyl group to yield the cyclic intermediate $\mathbf{4 4}$ which aromatized by loss of $\mathrm{H}_{2}$ to yield the pyridinethione $\mathbf{4 5}$ as demonstrated in (scheme 7). Confirmation of pyridinethiones $\mathbf{4 5}$ based on its compatible spectroscopic data. Thus, the ${ }^{1} \mathrm{H}-\mathrm{NMR}$ spectrum of compound $\mathbf{4 5 b}$ for example showed a singlet signal at $d=3.87 \mathrm{ppm}$ assigned for $\mathrm{OCH}_{3}$, a singlet signal at $\mathrm{d}=8.74 \mathrm{ppm}$ assigned to $\mathrm{OH}$, a singlet signal at $d=9.87 \mathrm{ppm}$ assigned for $\mathrm{NH}$ group in addition to a multiplet signal at $d=7.12-8.73 \mathrm{ppm}$ assigned to aromatic protons [34, 39-40].

Similarly, reaction of $\mathbf{3}$ with cyclopentylidenecynothiocetamide and cyclohexylideniecynothioacetamido 46a,b yield the azaspiro derivatives $49 a, b$ through the intermediate $47 a n d 48$ [41] as demonstrated in (scheme 8). Establishing the spiro derivatives was based on its compatible spectroscopic data and elemental analyses.

Coupling of propane-1,3-dione derivative 3 with diazotized aromatic amines in ethanol buffered with sodium acetate at $0-5{ }^{\circ} \mathrm{C}$ afforded the aryl hydrazones $51 \mathrm{a}-\mathrm{c}$. The aryl hydrazones were established based on its compatible spectroscopic data and elemental analyses. Condensation of $\mathbf{5 1}$ with malononitrile proceeded very readily by fusion in the presence of ammonium acetate to yield the pyridazine derivatives 54 a-c. Compound 54a-c were established based on spectral data (IR, ${ }^{1} \mathrm{H}-\mathrm{NMR}$ and mass spectra) and elemental analyses. Thus, ${ }^{1} \mathrm{H}$-NMR spectrum of 54 a for example revealed a singlet signal at $\mathrm{d}=3.99 \mathrm{ppm}$ assigned to $\mathrm{OCH}_{3}$, a singlet signal at $\mathrm{d}=8.71 \mathrm{ppm}$ assigned to $\mathrm{OH}$ group in addition to a multiplet signal at $\mathrm{d}=6.68-8.25$ ppm corresponding to aromatic protons and $\mathrm{NH}$. Also, the mass spectrum of the same compound revealed a molecular ion peak at $472\left(\mathrm{M}^{+}\right)$corresponding to the molecular formula $\mathrm{C}_{29} \mathrm{H}_{20} \mathrm{~N}_{4} \mathrm{O}_{3}$ and a number of fragments which agree with the proposed structure [42] (scheme 9).

\section{In vitro antimicrobial activity}

The newly synthesized compounds have been screened for antibacterial activity against some species of Gram-positive bacteria (Staphylococcus aureus and Bacillus subtilis) and Gram-negative bacteria (Escherichia coli and Pseudomonas aeuroginosa). Anti-fungal activities of the compounds were tested against yeast and mycelial fungi; Candida albicans and Aspergillus flavus, respectively. Each tested compound was dissolved in DMSO making a solution concentration of $1.00 \mathrm{mg} / \mathrm{mL}$ and loaded separately in paper discs of Whatman filter paper with equal diameter size $(10 \mathrm{~mm})$, Paper discs were sterilized in an autoclave. The paper discs loaded with the desired concentration of the complex solution, were placed aseptically in the petri dishes containing nutrient agar medium (agar $20 \mathrm{~g}+$ beef extract $3 \mathrm{~g}+$ peptone $5 \mathrm{~g}$ ) 
inoculated with Staphylococcus aureus, Bacillus subtilis, Escherichia coli, Pseudomonas aeuroginosa, Candida albicans and Aspergillus flavus. The petri dishes were incubated at $36^{\circ} \mathrm{C}$. The inhibition zones were recorded after 24 hrs of incubation in case of bacteria and yeast and after 5-6 days in case of mycelial fungi. Each treatment was replicated three times [43-44]. Ampicillin and clotrimazole, were used as a common standard antibiotic and antifungal agents, respectively. They prepared using the same procedure as above at the same concentration and solvents. The \% activity index was calculated for the tested compounds by using the given formula in equation (1).

\section{See Formula 1 in Supplementary Files.}

\section{Minimum inhibitory concentration (MIC) measurement}

The minimum inhibitory concentration (MIC) was determined using the disc diffusion technique by preparing discs containing 1.9-1000 $\mu \mathrm{g} / \mathrm{mL}$ of each compound against Gram-positive Staphylococcus aureus, Bacillus subtilisand Gram-negative Escherichia coli, Pseudomonas aeuroginosa. The anti-fungal activities of the compounds were tested against two fungi Candida albicans and Aspergillus flavus. The twofold dilutions of the solution were prepared. The microorganism suspensions at $10 \mathrm{CFU} / \mathrm{mL}$ (colony forming unit/mL) concentration were inoculated to the corresponding wells. The plates were incubated at $36{ }^{\circ} \mathrm{C}$ for $24 \mathrm{hrs}$ for the bacteria. The standard antibiotic ampicillin and antifungal colitrimazole was also recorded using the same procedure as above at the same concentration and solvents. At the end of the incubation period, the minimum inhibitory concentrations (MIC) values were recorded as the lowest concentration of the substance that had no visible turbidity. Control experiments with DMSO and uninoculated media were run parallel to the test compounds under the same condition. Table 1 and 2 illustrated the results of antimicrobial and antifungal activity and it's MIC. The results which are illustrated in Table 1 showed that most of tasted compounds were active against most of micro-organisms used. Both of compounds $\mathbf{4 5 c}$ and $\mathbf{5}$ showed no antibacterial or antifungal activity. On the other side each of compound 29 and 54a showed maximum antibacterial and antifungal activity. Compound 51a has no antibacterial activity against Gram-negative bacteria only, although it have broad spectrum antibacterial activity against Gram-positive bacteria and antifungal activity against $\boldsymbol{C}$. albicans and $\boldsymbol{A}$. flavus. On the other hands, compound $\mathbf{2 3}$ showed narrow spectrum antibacterial activity against $\boldsymbol{P}$. aeuroginosa (a Gram-negative bacteria) and $\boldsymbol{S}$. aureus (a Grampositive bacteria) and revealed no antibacterial activity against $\boldsymbol{E}$. coli (a Gram negative bacteria) and $\boldsymbol{B}$. subtilis (a Gram-positive bacteria), but in case of compound $40 \mathrm{~b}$ it has no antibacterial activity against $\boldsymbol{B}$. Subtilis only and has narrow range spectrum as antibacterial agent against $\boldsymbol{S}$. aureus, $\boldsymbol{E}$. Coli and $\boldsymbol{P}$. aeuroginosa with also small rang spectrum antifungal activity. All the other compounds $(3,35 b, 26,35 c, 35 a$, $40 \mathrm{a}, 10,16 \mathrm{a}, 14,49 \mathrm{a})$ indicated wide range spectrum antibacterial and antifungal activity.

From Table 2, we observed that compounds $29,35 a, 10,54 a$ and $16 a$ showed the lowest minimum inhibitory concentrations (MIC) for most tested bacteria and fungi, while compounds 40a, 40b, 35c and 49a exhibited high concentrations of MIC as compared with standard antimicrobial agents used.

\section{Experimental Section}

The melting points, the elemental analyses and the spectral data were recorded as reported in reference [29]. 
Preparation of 1-(1-hydroxynaphthalen-2-yl)-3-phenylpropane-1,3-dione (3) : A mixture of a-naphthol 1 (0.01 $\mathrm{mol})$, ethyl benzoylacetate $2(0.01 \mathrm{~mol})$ and zinc chloride $(5 \mathrm{gm})$ was exposed to microwave irradiation for 5 min, the reaction mixture was allowed to reach room temperature, then diluted with ethanol with stirring and the solid product that formed, was filtrated off and crystallized from ethanol to give (3;91\%) as brown crystals; M.P.72-74 $\mathrm{C}$; IR (KBr) n cm${ }^{-1}=3365(\mathrm{OH}), 3061$ (CH-arom), 2924 (CH-aliph), 1720, 1639 (2C=0) $\mathrm{cm}^{-1}$; ${ }^{1} \mathrm{H}-\mathrm{NMR}\left(\right.$ DMSO-d $\left.\mathrm{d}_{6}\right) \mathrm{d}=4.49\left(\mathrm{~s}, 2 \mathrm{H}, \mathrm{CH}_{2}\right), 7.20-8.68(\mathrm{~m}, 11 \mathrm{H}$, aromatic $\mathrm{H}), 8.69(\mathrm{~s}, 1 \mathrm{H}, \mathrm{OH}) ;{ }^{13} \mathrm{C}-\mathrm{NMR}(100$ MHz, DMSO-d $\left.\mathrm{d}_{6}\right) \mathrm{d}=54.6,118.6,123.1,124.2,125.2,126.0,126.3,127.5,127.5,127.7,127.7,128.2,129.6$, 132.6, 132.9, 135.6, 166.2, 193.2, 202.8; MS: $\mathrm{m} / \mathrm{z}(\%) 290\left(\mathrm{M}^{+}\right)$. Anal. calcd for $\mathrm{C}_{19} \mathrm{H}_{14} \mathrm{O}_{3}(290): \mathrm{C}, 78.61 ; \mathrm{H}$, 4.86; $0,16.53 \%$; Found: $C, 78.63 ; H, 4.88$.

Preparation of 2-((dimethylamino)methylene)-1-(1-hydroxynaphthalen-2-yl)-3-phenylpropane-1,3-dione (5): A mixture of $\mathbf{3}(0.01 \mathrm{~mol})$ and DMF-DMA $(0.01 \mathrm{~mol})$ in dioxane $(30 \mathrm{ml})$ was heated under reflux for $6 \mathrm{hrs}$. The reaction mixture was allowed to cool. The separated solid was filtered off, washed with ethanol and crystallized from ethanol to give $(5 ; 77 \%)$ as pale brown crystals; M.P. $173-175^{\circ} \mathrm{C} ; \mathrm{IR}(\mathrm{KBr}) \mathrm{n} \mathrm{cm}^{-1}=3422(\mathrm{OH})$, 3062 (CH-aromatic), 2932-2854 (CH-aliphatic), 1723, $1636(2 \mathrm{C}=0) \mathrm{cm}^{-1} ;{ }^{1} \mathrm{H}-\mathrm{NMR}$ (DMSO-d 6 ) d = $3.00(\mathrm{~s}, 6 \mathrm{H}$, $\left.2 \mathrm{CH}_{3}\right), 7.19$ (s, $1 \mathrm{H}, \mathrm{CH}$-oliffinic), 7.64-8.67 (m, 11H, aromatic $\left.\mathrm{H}\right), 8.68(\mathrm{~s}, 1 \mathrm{H}, \mathrm{OH}) ;{ }^{13} \mathrm{C}-\mathrm{NMR}(100 \mathrm{MHz}, \mathrm{DMSO}-$ $\left.d_{6}\right) d=44.5,44.5,116.2,122.4,124.3,126.1,126.7,127.6,127.6,128.1,128.1,128.2,128.6,129.1,130.1$, 132.4, 132.5, 138.1, 163.2, 166.5, 194.7, 198.0; MS: $\mathrm{m} / \mathrm{z}(\%) 345\left(\mathrm{M}^{+}\right)$. Anal. calcd for $\mathrm{C}_{22} \mathrm{H}_{19} \mathrm{NO}_{3}$ (345): C, 76.50; H, 5.54; N, 4.06\%; Found: C, 76.52; H, 5.56; N, 4.08\%.

Preparation of 2-(ethoxymethylene)-1-(1-hydroxynaphthalen-2-yl)-3-phenylpropane-1,3-dione (6): A mixture of $3(0.01 \mathrm{~mol})$ and triethoxy methane $(3 \mathrm{ml})$ in acetic anhydride $(10 \mathrm{ml})$ was heated under reflux for $12 \mathrm{hrs}$. The reaction mixture was allowed to cool. The separated solid was filtered off, washed with ethanol and crystallized from ethanol to give (6; 86\%) as pale brown crystals; M.P.120-122 ${ }^{\circ} \mathrm{C}$; IR $(\mathrm{KBr}) \mathrm{n} \mathrm{cm}^{-1}=3426(\mathrm{OH})$, 3062 (CH-arom), 2930 (CH-aliph), 1767, $1636(2 \mathrm{C}=0) \mathrm{cm}^{-1} ;{ }^{1} \mathrm{H}-\mathrm{NMR}\left(\mathrm{DMSO}_{6} \mathrm{~d}_{6}\right) \mathrm{d}=1.11\left(\mathrm{t}, 3 \mathrm{H}, \mathrm{CH}_{3}\right.$ ), 4.19 (q, $\left.2 \mathrm{H}, \mathrm{CH}_{2}\right), 6.33(\mathrm{~s}, 1 \mathrm{H}, \mathrm{CH}$-oliffinic), 7.29-8.23 (m, 11H, aromatic $\mathrm{H}), 8.68(\mathrm{~s}, 1 \mathrm{H}, \mathrm{OH}) ; \mathrm{MS}: \mathrm{m} / \mathrm{z}(\%) 346\left(\mathrm{M}^{+}\right)$. Anal. calcd for $\mathrm{C}_{22} \mathrm{H}_{18} \mathrm{O}_{4}$ (346): C, 76.29; $\mathrm{H}, 5.24 ; \mathrm{O}, 18.48 \%$; Found: $\mathrm{C}, 76.31 ; \mathrm{H}, 5.26$.

Preparation of 5-(1-hydroxy-2-naphthoyl)-4-phenyl-2-thioxo-1,2-dihydropyridine-3-carbonitrile (10): A mixture of $5(0.01 \mathrm{~mol})$ and cyanothioacetamide $7(0.01 \mathrm{~mol})$, in presence of sodium ethoxide $(30 \mathrm{ml})$ was heated under reflux for $24 \mathrm{hrs}$. The solution was allowed to cool and poured into crushed ice then acidified with $\mathrm{HCl}$. The separated solid was filtered off, washed with water and crystallized from dioxane to give $(10 ; 88 \%)$ as brown crystals; M.p.238-240 ${ }^{\circ} \mathrm{C}$; IR (KBr) n cm${ }^{-1}=3447(\mathrm{OH}), 3423(\mathrm{NH}), 3062$ (CH-arom), 2209 (CN), 1636 (CO) $\mathrm{cm}^{-1} ;{ }^{1} \mathrm{H}-\mathrm{NMR}\left(\right.$ DMSO-d 6 ) d = 7.20-8.24 $(\mathrm{m}, 13 \mathrm{H}$, aromatic $\mathrm{H}$ and $\mathrm{NH}), 8.70(\mathrm{~s}, 1 \mathrm{H}, \mathrm{OH}) ;{ }^{13} \mathrm{C}-\mathrm{NMR}(100$ MHz, DMSO-d $\left.{ }_{6}\right) d=107.1,117.0,118.2,122.3,123.2,126.3,126.4,126.8,127.3,127.3,127.5,127.5,128.3$,

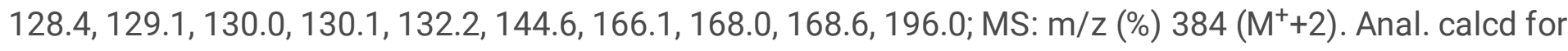
$\mathrm{C}_{23} \mathrm{H}_{14} \mathrm{~N}_{2} \mathrm{O}_{2} \mathrm{~S}$ (382): C, 72.23; $\mathrm{H}, 3.69 ; \mathrm{N}, 7.33 \%$; Found: C, 72.25; H, 3.71; N, 7.35\%.

Preparation of (1-hydroxynaphthalen-2-yl)(3-phenyl-1H-pyrazol-4-yl)methanone (14): Method (A): A mixture of $5(0.01 \mathrm{~mol})$ and hydrazine hydrate $(10 \mathrm{ml})$ was heated under reflux for $12 \mathrm{hrs}$. The reaction mixture was 
allowed to cool and poured into crushed ice. The separated solid was filtered off, washed with water and crystallized from DMF to give $(14 ; 80 \%)$.

Method (B): A mixture of $6(0.01 \mathrm{~mol})$ and hydrazine hydrate $(10 \mathrm{ml})$ was heated under reflux for $12 \mathrm{hrs}$. The reaction mixture was allowed to cool and poured into crushed ice. The separated solid was filtered off, washed with water and crystallized from DMF to give $(14 ; 79 \%)$ as white crystals; M.P.> $300^{\circ} \mathrm{C}$; IR $(\mathrm{KBr}) \mathrm{n} \mathrm{cm}^{-}$ $1=3300(\mathrm{OH}), 3228(\mathrm{NH}), 3062$ (CH-aromatic), $1670(\mathrm{CO}) \mathrm{cm}^{-1} ;{ }^{1} \mathrm{H}-\mathrm{NMR}\left(\right.$ DMSO-d $\left._{6}\right) \mathrm{d}=7.22(\mathrm{~s}, 1 \mathrm{H}, \mathrm{CH}-$ pyrazole), 7.31-8.71 (m, 12H, aromatic and $\mathrm{NH}), 8.73(\mathrm{~s}, 1 \mathrm{H}, \mathrm{OH}) ; \mathrm{MS}: \mathrm{m} / \mathrm{z}(\%) 314\left(\mathrm{M}^{+}\right)$. Anal. calcd for $\mathrm{C}_{20} \mathrm{H}_{14} \mathrm{~N}_{2} \mathrm{O}_{2}$ (314): C, 76.42; $\mathrm{H}, 4.49 ; \mathrm{N}, 8.91 \%$; Found: $\mathrm{C}, 76.44 ; \mathrm{H}, 4.51 ; \mathrm{N}, 8.93 \%$.

\section{General procedure for preparation of compounds (16a,b and 18$)$ :}

A mixture of $5(0.01 \mathrm{~mol})$ with urea $(0.01 \mathrm{~mol})$, thiourea $(0.01 \mathrm{~mol})$ and guanidine hydrochloride $(0.01 \mathrm{~mol})$, in presence of sodium ethoxide $(30 \mathrm{ml})$ was heated under reflux for $24 \mathrm{hrs}$. The solutions were allowed to cool and poured into crushed ice then acidified with $\mathrm{HCl}$. The separated solids were filtered off, washed with water and crystallized from the proper solvent to give $(16 \mathbf{a}, \mathbf{b}$ and 18$)$.

5-(1-hydroxy-2-naphthoyl)-4-phenylpyrimidin-2(1H)-one (16a): It was obtained as beige crystals from DMF; yield (79\%); M.P.> 300 ${ }^{\circ}$; IR (KBr) n cm ${ }^{-1}=3447,3423(\mathrm{OH} / \mathrm{NH}), 3061\left(\mathrm{CH}\right.$-aromatic), 1740, $1641(2 \mathrm{C}=0) \mathrm{cm}^{-}$ 1; ${ }^{1} \mathrm{H}-\mathrm{NMR}\left(\mathrm{DMSO}_{\mathrm{d}} \mathrm{d}_{6}\right) \mathrm{d}=7.22(\mathrm{~s}, 1 \mathrm{H}, \mathrm{CH}$-pyrimidine), 7.65-8.70 $(\mathrm{m}, 12 \mathrm{H}$, aromatic $\mathrm{H}$ and $\mathrm{NH}), 8.71(\mathrm{~s}, 1 \mathrm{H}$, $\mathrm{OH}) ; \mathrm{MS}: \mathrm{m} / \mathrm{z}(\%) 342\left(\mathrm{M}^{+}\right)$. Anal. calcd for $\mathrm{C}_{21} \mathrm{H}_{14} \mathrm{~N}_{2} \mathrm{O}_{3}$ (342): C, 73.68; $\mathrm{H}, 4.12 ; \mathrm{N}, 8.18 \%$; Found: $\mathrm{C}, 73.70 ; \mathrm{H}$, $4.14 ; \mathrm{N}, 8.20 \%$.

(1-hydroxynaphthalen-2-yl)(4-phenyl-2-thioxo-1,2-dihydropyrimidin-5-yl)methanone (16b): It was obtained as brown crystals from DMF; yield (72\%); M.P.> 300 $\mathrm{C}$; IR $(\mathrm{KBr}) \mathrm{n} \mathrm{cm}^{-1}=3449,3400(\mathrm{OH} / \mathrm{NH}), 1645(\mathrm{C}=0) \mathrm{cm}^{-1}$; ${ }^{1} \mathrm{H}-N M R\left(D M S O-d_{6}\right) d=7.19(\mathrm{~s}, 1 \mathrm{H}, \mathrm{CH}$-pyrimidine), 7.59-8.67 (m, 12H, aromatic $\mathrm{H}$ and $\mathrm{NH}), 8.68(\mathrm{~s}, 1 \mathrm{H}, \mathrm{OH})$; MS: m/z (\%) $358\left(\mathrm{M}^{+}\right)$. Anal. calcd for $\mathrm{C}_{21} \mathrm{H}_{14} \mathrm{~N}_{2} \mathrm{O}_{2} \mathrm{~S}$ (358): C, 70.37; $\mathrm{H}, 3.94 ; \mathrm{N}, 7.82$ \%; Found: $\mathrm{C}, 70.39 ; \mathrm{H}$, $3.96 ; \mathrm{N}, 7.84 \%$.

(2-amino-4-phenylpyrimidin-5-yl)(1-hydroxynaphthalen-2-yl)methanone (18): It was obtained as brown crystals from dioxane; yield (71\%); M.P. $250-252^{\circ} \mathrm{C}$; IR (KBr) n cm${ }^{-1}=3449,3400\left(\mathrm{OH} / \mathrm{NH}_{2}\right), 1642(\mathrm{C}=0) \mathrm{cm}^{-1}$; ${ }^{1} \mathrm{H}-\mathrm{NMR}\left(\right.$ DMSO-d $\left.\mathrm{d}_{6}\right) \mathrm{d}=6.20\left(\mathrm{~s}, 2 \mathrm{H}, \mathrm{NH}_{2}\right), 7.31-8.39(\mathrm{~m}, 12 \mathrm{H}$, aromatic $\mathrm{H}), 8.67(\mathrm{~s}, 1 \mathrm{H}, \mathrm{OH}) ;{ }^{13} \mathrm{C}-\mathrm{NMR}(100$ MHz, DMSO-d $\left.{ }_{6}\right) d=118.0,119.3,123.2,124.3,124.8,126.4,126.4,126.4,126.6,127.6,128.2,128.7,128.9$, $128.9,130.7,132.7,155.3,162.7,165.8,166.3,194.0 ; \mathrm{MS}: \mathrm{m} / \mathrm{z}(\%) 341\left(\mathrm{M}^{+}\right)$. Anal. calcd for $\mathrm{C}_{21} \mathrm{H}_{15} \mathrm{~N}_{3} \mathrm{O}_{2}$ (341): C, 73.89; H, 4.43; N, 12.31\%; Found: C, 73.91; H, 4.45; N, 12.33\%.

Preparation of (1-hydroxynaphthalen-2-yl)(3-phenylisoxazol-4-yl)methanone (20): A mixture of 5 (0.01 mol), hydroxylamine hydrochloride in ethanol $(30 \mathrm{ml})$ containing anhydrous sodium acetate $(1 \mathrm{~g})$ was heated under reflux for $24 \mathrm{hrs}$. The reaction mixture was allowed to cool and poured into cold water $(60 \mathrm{ml})$. The separated solid was filtered off and crystallized from ethanol to give (20; 71\%) as brown crystals; M.P. $150-152^{\circ} \mathrm{C}$; IR (KBr) n cm${ }^{-1}=3425(\mathrm{OH}), 3060$ (CH-aromatic), $1636(\mathrm{C}=0) \mathrm{cm}^{-1} ;{ }^{1} \mathrm{H}-\mathrm{NMR}\left(\mathrm{DMSO}^{-} \mathrm{d}_{6}\right) \mathrm{d}=7.21(\mathrm{~s}, 1 \mathrm{H}, \mathrm{CH}-$ 
isoxazole), 7.31-8.70 (m, 11H, aromatic H), $8.71(\mathrm{~s}, 1 \mathrm{H}, \mathrm{OH}) ; \mathrm{MS}: \mathrm{m} / \mathrm{z}(\%) 315\left(\mathrm{M}^{+}\right)$. Anal. calcd for $\mathrm{C}_{20} \mathrm{H}_{13} \mathrm{NO}_{3}$ (315): C, 76.18; H, 4.16; N, 4.44 \%; Found:C, 76.20; H, 4.18; N, 4.46 \%.

Preparation of (2-(3-Phenylisoxazol-5-yl)naphthalen-1-ol (23): A mixture of 3 (0.01 mol), hydroxylamine hydrochloride $(0.01 \mathrm{~mol})$ in ethanol $(30 \mathrm{ml})$ containing anhydrous sodium acetate $(1 \mathrm{~g})$ was heated under reflux for $24 \mathrm{hrs}$. The reaction mixture was allowed to cool and poured into cold water $(60 \mathrm{ml})$. The separated solid was filtered off and crystallized from ethanol to give $(23 ; 80 \%)$ as beige crystals; M.p. $132-134^{\circ} \mathrm{C}$; IR $(\mathrm{KBr}) \mathrm{n} \mathrm{cm}^{-1}=3382(\mathrm{OH}), 3061$ (CH-aromatic) $\mathrm{cm}^{-1} ;{ }^{1} \mathrm{H}-\mathrm{NMR}\left(\right.$ DMSO-d $\left._{6}\right) \mathrm{d}=7.21(\mathrm{~s}, 1 \mathrm{H}, \mathrm{CH}$ - isoxazol), $7.32-$ $8.54(\mathrm{~m}, 11 \mathrm{H}$, aromatic $\mathrm{H}), 8.69(\mathrm{~s}, 1 \mathrm{H}, \mathrm{OH}) ;{ }^{13} \mathrm{C}-\mathrm{NMR}(100 \mathrm{MHz}$, DMSO-d 6 ) $d=99.6,118.7,120.6,123.5$, $124.1,126.1,126.3,126.5,126.5,127.3,127.5,127.6,127.9,128.8,128.8,132.4,161.0,163.2,170.1 ; \mathrm{MS}: \mathrm{m} / \mathrm{z}$ (\%) $287\left(\mathrm{M}^{+}\right)$. Anal. calcd for $\mathrm{C}_{19} \mathrm{H}_{13} \mathrm{NO}_{2}$ (287): $\mathrm{C}, 79.43 ; \mathrm{H}, 4.56 ; \mathrm{N}, 4.88 \%$; Found:C, 79.45; $\mathrm{H}, 4.58 ; \mathrm{N}, 4.90 \%$.

Preparation of 6-(1-hydroxynaphthalen-2-yl)-2-oxo-4-phenyl-1,2-dihydropyridine-3-carbonitrile (26): A mixture of $3(0.01 \mathrm{~mol})$, malononitrile $(0.01 \mathrm{~mol})$ in ethanol $(30 \mathrm{ml})$ containing catalytic amount of sodium ethoxide was heated under reflux for $12 \mathrm{hrs}$. The reaction mixture was allowed to cool and poured into crushed ice then acidified with $\mathrm{HCl}$. The separated solid was filtered off, washed with water and crystallized from ethanol to give $(26 ; 69 \%)$ as brown crystals; M.P.163-165 $\mathrm{C}$; IR $(\mathrm{KBr}) \mathrm{n} \mathrm{cm}^{-1}=3311,3294(\mathrm{OH} / \mathrm{NH}), 3062(\mathrm{CH}-$ aromatic), $2193(\mathrm{CN}), 1639$ (C=0) cm ${ }^{-1} ;{ }^{1} \mathrm{H}-\mathrm{NMR}$ (DMSO-d $\mathrm{d}_{6}$ ) d = 7.16 (s, 1H, CH-Pyridine), 7.51-8.63 (m, 12H, aromatic $\mathrm{H}$ and $\mathrm{NH}), 8.64(\mathrm{~s}, 1 \mathrm{H}, \mathrm{OH}) ;{ }^{13} \mathrm{C}-\mathrm{NMR}\left(100 \mathrm{MHz}\right.$, DMSO-d $\left.\mathrm{d}_{6}\right) \mathrm{d}=108.3,118.3,118.6,120.1,123.4$, $124.1,125.8,126.9,127.1,127.2,127.6,127.6,127.9,127.9,128.3,133.9,135.2,153.6,155.2,155.3,157.8$, 162.3; MS: $\mathrm{m} / \mathrm{z}(\%) 338\left(\mathrm{M}^{+}\right)$. Anal. calcd for $\mathrm{C}_{22} \mathrm{H}_{14} \mathrm{~N}_{2} \mathrm{O}_{2}$ (338): $\mathrm{C}, 78.09 ; \mathrm{H}, 4.17 ; \mathrm{N}, 8.28 \%$; Found:C, 78.11; $\mathrm{H}$, $4.19 ; \mathrm{N}, 8.30 \%$.

Preparation of 2-amino-5-(1-hydroxy-2-naphthoyl)-4-phenylthiophene-3-carbonitrile (29): Equimolar amounts of $3(0.01 \mathrm{~mol})$, malononitrile and elemental sulfur $(0.01 \mathrm{~mol})$ in ethanol $(30 \mathrm{ml})$ containing piperidine were refluxed for $15 \mathrm{hrs}$, poured onto cold water $(30 \mathrm{ml})$ and acidified with $\mathrm{HCl}(\mathrm{pH}=3)$. The solid product thus formed was filtered off and crystallized from ethanol to give $(29 ; 80 \%)$ as yellow crtstals; M.p. $130-132^{\circ} \mathrm{C}$; IR $(\mathrm{KBr}) \mathrm{n} \mathrm{cm}^{-1}=3421,3400\left(\mathrm{OH} / \mathrm{NH}_{2}\right), 3061$ (CH-aromatic), $2192(\mathrm{CN}), 1639$ (C=0) cm ${ }^{-1} ;{ }^{1} \mathrm{H}-\mathrm{NMR}\left(\mathrm{DMSO}-\mathrm{d}_{6}\right) \mathrm{d}$ $=7.20-8.68\left(\mathrm{~m}, 13 \mathrm{H}\right.$, aromatic $\left.\mathrm{H}_{\text {and }} \mathrm{NH}_{2}\right), 8.69(\mathrm{~s}, 1 \mathrm{H}, \mathrm{OH}) ; \mathrm{MS}: \mathrm{m} / \mathrm{z}(\%) 370\left(\mathrm{M}^{+}\right)$. Anal. calcd for $\mathrm{C}_{22} \mathrm{H}_{14} \mathrm{~N}_{2} \mathrm{O}_{2} \mathrm{~S}$ (370): C, 71.33; $\mathrm{H}, 3.81 ; \mathrm{N}, 7.56 \%$; Found:C, 71.35; $\mathrm{H}, 3.84 ; \mathrm{N}, 7.58 \%$.

General procedure for preparation of compounds (35a-c): A mixture of 31a-c (which prepared by amixture of 3 and $30 \mathrm{a}-\mathrm{c}$ in ethanol/piperidine refluxing) $(0.01 \mathrm{~mol})$, dimedone $(0.01 \mathrm{~mol})$ and ammonium acetate $(2 \mathrm{gm})$ was fused for $30 \mathrm{~min}$. The reaction mixture was allowed to cool, then triturated with ethanol. The separated solid was filtered off, washed with water and crystallized from the proper solvent to give 35a-c.

3-(1-hydroxy-2-naphthoyl)-7,7-dimethyl-2,4-diphenyl-4,6,7,8-tetrahydroquinolin-5(1H)-one (35a): It was obtained as yellow crystals from dioxane; yield (86\%); M.P.280-282 ${ }^{\circ} \mathrm{C}$; IR $(\mathrm{KBr}) \mathrm{n} \mathrm{cm}^{-1}=3402,3400(\mathrm{OH} / \mathrm{NH})$, 3059 (CH-aromatic), 2954-2870 (CH-aliphatic), 1642, 1620 (2C=0) $\mathrm{cm}^{-1} ;{ }^{1} \mathrm{H}-\mathrm{NMR}$ (DMSO-d $\left.\mathrm{d}_{6}\right) \mathrm{d}=0.86$ (s, 3H, $\left.\mathrm{CH}_{3}\right), 0.99\left(\mathrm{~s}, 3 \mathrm{H}, \mathrm{CH}_{3}\right), 2.73\left(\mathrm{~s}, 2 \mathrm{H}, \mathrm{CH}_{2}\right), 2.89\left(\mathrm{~s}, 2 \mathrm{H}, \mathrm{CH}_{2}\right), 4.80$ (s, $1 \mathrm{H}, \mathrm{CH}$-pyridine), 7.14-8.70 (m, 17H, 
aromatic $\mathrm{H}$ and $\mathrm{NH}), 8.70$ (s, $1 \mathrm{H}, \mathrm{OH}) ; \mathrm{MS}: \mathrm{m} / \mathrm{z}(\%) 499\left(\mathrm{M}^{+}\right)$. Anal. calcd for $\mathrm{C}_{34} \mathrm{H}_{29} \mathrm{NO}_{3}(499): \mathrm{C}, 81.74 ; \mathrm{H}$, 5.85; N, 2.80\%; Found:C, 81.76; H, 5.87; N, 2.82\%.

3-(1-hydroxy-2-naphthoyl)-4-(4-methoxyphenyl)-7,7-dimethyl-2-phenyl-4,6,7,8-tetrahydro-quinolin-5(1H)-one (35b): It was obtained as yellow crystals from dioxane; yield (80\%); M.P.277-279 C; IR (KBr) n cm-1 = 3371 (OH), 3255 (NH), 3059 (CH-aromatic), 2954-2835 (CH-aliphatic), 1639, 1620 (2C=0) cm-1; ${ }^{1} \mathrm{H}-\mathrm{NMR}_{\text {(DMSO-d }}$ ) $\mathrm{d}=0.82\left(\mathrm{~s}, 3 \mathrm{H}, \mathrm{CH}_{3}\right), 1.19\left(\mathrm{~s}, 3 \mathrm{H}, \mathrm{CH}_{3}\right), 2.70\left(\mathrm{~s}, 2 \mathrm{H}, \mathrm{CH}_{2}\right), 2.86\left(\mathrm{~s}, 2 \mathrm{H}, \mathrm{CH}_{2}\right), 3.70\left(\mathrm{~s}, 3 \mathrm{H}, \mathrm{OCH}_{3}\right), 4.49(\mathrm{~s}, 1 \mathrm{H}, \mathrm{CH}-$ pyridine), 7.21-8.28 (m, 16H, aromatic $\mathrm{H}$ and $\mathrm{NH}), 8.45(\mathrm{~s}, 1 \mathrm{H}, \mathrm{OH}) ;{ }^{13} \mathrm{C}-\mathrm{NMR}\left(100 \mathrm{MHz}, \mathrm{DMSO}-\mathrm{d}_{6}\right) \mathrm{d}=29.2$, 29.2, 33.8, 41.0, 41.4, 52.3, 57.8, 107.0, 113.2, 116.3, 116.3, 122.0, 123.1, 124.3, 126.4, 126.8, 127.2, 127.6, 127.6, 127.6, 127.8, 128.0, 128.2, 128.9, 132.1, 132.1, 132.7, 137.2, 137.2, 143.6, 150.2, 159.5, 166.0, 193.4, 195.1; MS: m/z (\%) $529\left(\mathrm{M}^{+}\right)$. Anal. calcd for $\mathrm{C}_{35} \mathrm{H}_{31} \mathrm{NO}_{4}(529)$ : C, 79.37; H, 5.90; N, 2.64; Found:C, 79.39; $\mathrm{H}$, $5.92 ; \mathrm{N}, 2.66$.

\section{4-(4-chlorophenyl)-3-(1-hydroxy-2-naphthoyl)-7,7-dimethyl-2-phenyl-4,6,7,8-tetrahydroquinolin-5(1H)-one} (35c): It was obtained as pale yellow crystals from dioxane; yield (83\%); M.P.290-292 ${ }^{\circ} \mathrm{C}$; IR (KBr) $\mathrm{n} \mathrm{cm}^{-1}=$ $3356(\mathrm{OH}), 3271(\mathrm{NH}), 3059$ (CH-aromatic), 2954-2870 (CH-aliphatic), 1643, 1620 (2C=O) cm ${ }^{-1}$; ${ }^{1} \mathrm{H}-\mathrm{NMR}$ $\left(\right.$ DMSO-d $\left._{6}\right) \mathrm{d}=0.83\left(\mathrm{~s}, 3 \mathrm{H}, \mathrm{CH}_{3}\right), 1.20\left(\mathrm{~s}, 3 \mathrm{H}, \mathrm{CH}_{3}\right), 2.70\left(\mathrm{~s}, 2 \mathrm{H}, \mathrm{CH}_{2}\right), 2.89\left(\mathrm{~s}, 2 \mathrm{H}, \mathrm{CH}_{2}\right), 4.49(\mathrm{~s}, 1 \mathrm{H}, \mathrm{CH}-$ pyridine), 7.28-8.11 (m, 16H, aromatic $\mathrm{H}$ and $\mathrm{NH}), 8.50(\mathrm{~s}, 1 \mathrm{H}, \mathrm{OH}) ; \mathrm{MS}: \mathrm{m} / \mathrm{z}(\%) 533\left(\mathrm{M}^{+}\right)$. Anal. calcd for $\mathrm{C}_{34} \mathrm{H}_{28} \mathrm{ClNO}_{3}$ (533): C, 76.47; H, 5.28; N, 2.62; Found:C, 76.49; H, 5.30; N, 2.64\%.

General procedure for preparation of compounds $(40 \mathrm{a}, \mathrm{b})$ : A mixture of $\mathbf{3}(0.01 \mathrm{~mol})$ and arylidenemalononitriles $(36 \mathrm{a}, \mathrm{b})(0.01 \mathrm{~mol})$ in ethanol $(30 \mathrm{ml})$ containing catalytic amount of piperidine was heated under reflux for $12 \mathrm{hrs}$. The reaction mixture was allowed to cool and poured into crushed ice then acidified with $\mathrm{HCl}$. The separated solid was filtered off, washed with water and crystallized from the proper solvent to give $(40 a, b)$.

2-amino-4-(4-chlorophenyl)-5-(1-hydroxy-2-naphthoyl)-6-phenyl-4H-pyran-3-carbonitrile (40a): It was obtained as brown crystals from ethanol; yield (92\%); M.P.162-164 ${ }^{\circ} \mathrm{C}$; IR (KBr) n cm ${ }^{-1}: 3448,3421\left(\mathrm{OH} / \mathrm{NH}_{2}\right), 3063(\mathrm{CH}-$ aromatic), 2929 (CH-aliphatic), $2191(\mathrm{CN}), 1630$ (C=0) cm ${ }^{-1} ;{ }^{1} \mathrm{H}-\mathrm{NMR}\left(\mathrm{DMSO}_{\mathrm{d}}\right) \mathrm{d}=4.40$ (s, 1H, 4H-pyrane), 7.23-8.72 (m, 17H, aromatic $\mathrm{H}$ and $\left.\mathrm{NH}_{2}\right), 8.74(\mathrm{~s}, 1 \mathrm{H}, \mathrm{OH}) ;{ }^{13} \mathrm{C}-\mathrm{NMR}\left(100 \mathrm{MHz}, \mathrm{DMSO}-\mathrm{d}_{6}\right) \mathrm{d}=43.7,60.3$, 118.9, 122.1, 123.4, 124.2, 125.2, 125.2, 126.2, 126.8, 126.8, 126.8, 126.9, 126.9, 127.5, 127.5, 127.6, 127.6, 128.1, 128.2, 131.3, 131.3, 132.6, 133.2, 135.0, 140.8, 163.3, 165.2, 193.5; MS: m/z (\%) 480 (M+2). Anal. calcd for $\mathrm{C}_{29} \mathrm{H}_{19} \mathrm{ClN}_{2} \mathrm{O}_{3}$ (478): C, 72.73; H, 4.00;N, 5.85\%; Found:C, 72.75; H, 4.02; N, 5.87\%.

\section{2-amino-5-(1-hydroxy-2-naphthoyl)-4-(4-hydroxyphenyl)-6-phenyl-4H-pyran-3-carbonitrile (40b): It was}

obtained as brown crystals from ethanol; yield (90\%); M.P.200-202 ${ }^{\circ} \mathrm{C}$; IR (KBr) n cm ${ }^{-1}: 3447,3390\left(\mathrm{OH} / \mathrm{NH}_{2}\right)$, 3062 (CH-aromatic), 2928 (CH-aliphatic), 2196 (CN), $1630(\mathrm{C}=0) \mathrm{cm}^{-1} ;{ }^{1} \mathrm{H}-\mathrm{NMR}\left(\mathrm{DMSO}-\mathrm{d}_{6}\right) \mathrm{d}=4.20(\mathrm{~s}, 1 \mathrm{H}$, 4H-pyrane), 6.87 (s, 2H, NH$\left.{ }_{2}\right), 6.90-8.71$ (m, 15H, aromatic H), 8.72 (s, 1H, OH), 10.00 (s, 1H, OH); MS: m/z (\%) $460\left(\mathrm{M}^{+}\right)$. Anal. calcd for $\mathrm{C}_{29} \mathrm{H}_{20} \mathrm{~N}_{2} \mathrm{O}_{4}$ (460): C, 75.64; $\mathrm{H}, 4.38 ; \mathrm{N}, 6.08 \%$; Found:C, 75.66; H, 4.40; N, 6.10\%. 
General procedure for preparation of compounds (45a-c): A mixture of $3(0.01 \mathrm{~mol})$ and arylidenecyanothioacetamide $(41 \mathrm{a}-\mathrm{c})(0.01 \mathrm{~mol})$ in ethanol $(30 \mathrm{ml})$ containing catalytic amount of TEA was heated under reflux for $12 \mathrm{hrs}$. The reaction mixture was allowed to cool and poured into crushed ice then acidified with $\mathrm{HCl}$. The separated solid was filtered off, washed with water and crystallized from the proper solvent to give (45 a-c).

5-(1-hydroxy-2-naphthoyl)-4,6-diphenyl-2-thioxo-1,2-dihydropyridine-3-carbonitrile (45a): It was obtained as pale yellow crystals from ethanol; yield (78\%); M.P.146-148 ${ }^{\circ}$ C; IR (KBr) n cm${ }^{-1}$ : $3444(\mathrm{OH}), 3390(\mathrm{NH}), 3059$ (CH-aromatic), 2191 (CN), $1620(\mathrm{C}=0) \mathrm{cm}^{-1} ;{ }^{1} \mathrm{H}-\mathrm{NMR}\left(\mathrm{DMSO}^{-\mathrm{d}_{6}}\right) \mathrm{d}=7.23-8.73(\mathrm{~m}, 17 \mathrm{H}$, aromatic $\mathrm{H}$ and $\mathrm{NH})$, $8.74(\mathrm{~s}, 1 \mathrm{H}, \mathrm{OH})$; $\mathrm{MS}: \mathrm{m} / \mathrm{z}(\%) 458\left(\mathrm{M}^{+}\right)$. Anal. calcd for $\mathrm{C}_{29} \mathrm{H}_{18} \mathrm{~N}_{2} \mathrm{O}_{2} \mathrm{~S}$ (458): C, 75.96; $\mathrm{H}, 3.96 ; \mathrm{N}, 6.11 \%$; Found:C, 75.98; $\mathrm{H}, 3.98 ; \mathrm{N}, 6.13 \%$.

5-(1-hydroxy-2-naphthoyl)-4-(4-methoxyphenyl)-6-phenyl-2-thioxo-1,2-dihydropyridine-3-carbonitrile (45b): It was obtained as pale yellow crystals from ethanol; yield (82\%); M.P. $150-152^{\circ} \mathrm{C}$; IR $(\mathrm{KBr}) \mathrm{n} \mathrm{cm}^{-1}=3448(\mathrm{OH})$, $3387(\mathrm{NH}), 3059$ (CH-aromatic), 2931 (CH-aliphatic), $2194(\mathrm{CN}), 1630(\mathrm{C}=0) \mathrm{cm}^{-1} ;{ }^{1} \mathrm{H}-\mathrm{NMR}\left(\mathrm{DMSO}-\mathrm{d}_{6}\right) \mathrm{d}=$ $3.87\left(\mathrm{~s}, 3 \mathrm{H}, \mathrm{OCH}_{3}\right), 7.12-8.73(\mathrm{~m}, 15 \mathrm{H}$, aromatic $\mathrm{H}), 8.74(\mathrm{~s}, 1 \mathrm{H}, \mathrm{OH}), 9.87(\mathrm{~s}, 1 \mathrm{H}, \mathrm{NH}) ;{ }^{13} \mathrm{C}-\mathrm{NMR}(100 \mathrm{MHz}$, DMSO- $\left.\mathrm{d}_{6}\right) \mathrm{d}=57.6,108.2,111.9,118.2,118.2,118.8,122.3,124.6,124.8,125.2,126.4,126.8,126.8,127.3$, 127.3, 127.5, 127.6, 128.0, 128.1, 128.7, 132.1, 132.1, 132.7, 135.2, 155.8, 160.8, 163.7, 165.2, 172.6, 193.3; MS: $\mathrm{m} / \mathrm{z}(\%) 488\left(\mathrm{M}^{+}\right)$. Anal. calcd for $\mathrm{C}_{30} \mathrm{H}_{20} \mathrm{~N}_{2} \mathrm{O}_{3} \mathrm{~S}$ (488): C, 73.75; $\mathrm{H}, 4.13 ; \mathrm{N}, 5.73 \%$; Found:C, 73.77; $\mathrm{H}$, $4.15 ; \mathrm{N}, 5.75 \%$.

4-(4-chlorophenyl)-5-(1-hydroxy-2-naphthoyl)-6-phenyl-2-thioxo-1,2-dihydropyridine-3-carbonitrile (45c): It was obtained as yellow crystals from ethanol; yield (88\%); M.P.136-138 ${ }^{\circ} \mathrm{C}$; IR (KBr) n cm ${ }^{-1}=3390(\mathrm{OH}), 3255$ $(\mathrm{NH}), 3059$ (CH-aromatic), $2191(\mathrm{CN}), 1635(\mathrm{C}=0) \mathrm{cm}^{-1} ;{ }^{1} \mathrm{H}-\mathrm{NMR}\left(\mathrm{DMSO}_{\mathrm{d}}\right) \mathrm{d}=7.23-8.73(\mathrm{~m}, 16 \mathrm{H}$, aromatic $\mathrm{H}$ and $\mathrm{NH}), 8.74(\mathrm{~s}, 1 \mathrm{H}, \mathrm{OH}) ; \mathrm{MS}: \mathrm{m} / \mathrm{z}(\%) 494\left(\mathrm{M}^{+}+2\right)$. Anal. calcd for $\mathrm{C}_{29} \mathrm{H}_{17} \mathrm{ClN}_{2} \mathrm{O}_{2} \mathrm{~S}$ (492): C, 70.65; $\mathrm{H}, 3.48$; N, 5.68\%; Found:C, 70.67; H, 3.50; N, 5.71\%.

General procedure for preparation of compounds $(49 a, b)$ : A mixture of $3(0.01 \mathrm{~mol})$ and 2-cyano-2cyclopentylidene-ethaneethioamide $\mathbf{4 6 a}(0.01 \mathrm{~mol})$ or 2-cyano-2-cyclohexylidene-ethaneethioamide $\mathbf{4 6 b}(0.01$ $\mathrm{mol})$ in ethanol $(30 \mathrm{ml})$ containing catalytic amount of piperidine was heated under reflux for $24 \mathrm{hrs}$. The reaction mixture was allowed to cool and poured into crushed ice then acidified with $\mathrm{HCl}$. The separated solid was filtered off, washed with water and crystallized from the proper solvent to give $(49 a, b)$.

10-(1-hydroxy-2-naphthoyl)-9-phenyl-7-thioxo-8-azaspiro[4.5]dec-9-ene-6-carbonitrile (49a): It was obtained as pale yellow crystals from ethanol; yield (74\%); M.P.180-182 ${ }^{\circ} \mathrm{C}$; IR $(\mathrm{KBr}) \mathrm{n} \mathrm{cm}^{-1}=3387(\mathrm{OH}), 3248(\mathrm{NH}), 3059$ (CH-aromatic), 2935-2854 (CH-aliphatic), $2183(\mathrm{CN}), 1627$ (C=0) cm ${ }^{-1} ;{ }^{1} \mathrm{H}-\mathrm{NMR}$ (DMSO-d $\mathrm{d}_{6}$ ) d = 0.85-1.91 (m, $\left.4 \mathrm{H}, 2 \mathrm{CH}_{2}\right), 1.95\left(\mathrm{~s}, 1 \mathrm{H}, \mathrm{CH}\right.$-pyridine), 2.00-2.94 (m, 4H, 2 $\left.\mathrm{CH}_{2}\right), 7.14-8.69(\mathrm{~m}, 11 \mathrm{H}$, aromatic $\mathrm{H}), 8.70(\mathrm{~s}, 1 \mathrm{H}, \mathrm{OH})$ ), $9.40(\mathrm{~s}, 1 \mathrm{H}, \mathrm{NH}) ;{ }^{13} \mathrm{C}-\mathrm{NMR}\left(100 \mathrm{MHz}, \mathrm{DMSO}-\mathrm{d}_{6}\right) \mathrm{d}=27.8,27.8,38.3,38.3,39.0,57.8,116.2,119.2,122.3$, 123.3, 123.9, 126.1, 126.4, 126.9, 127.3, 127.3, 127.5, 127.8, 128.3, 128.3, 128.8, 132.5, 135.2, 155.3, 166.7, 193.2, 198.9; MS: $\mathrm{m} / \mathrm{z}(\%) 440\left(\mathrm{M}^{+}+2\right)$. Anal. calcd for $\mathrm{C}_{27} \mathrm{H}_{22} \mathrm{~N}_{2} \mathrm{O}_{2} \mathrm{~S}(438)$ : C, 73.95; $\mathrm{H}, 5.06 ; \mathrm{N}, 6.39 \%$; Found:C, 73.97; $H, 5.08 ; \mathrm{N}, 6.41 \%$. 
5-(1-hydroxy-2-naphthoyl)-4-phenyl-2-thioxo-3-azaspiro[5.5]undec-4-ene-1-carbonitrile (49b): It was obtained as pale yellow crystals from dioxane; yield (87\%); M.P.278-280 ${ }^{\circ}$; IR (KBr) n cm${ }^{-1}=3394(\mathrm{OH}), 3325(\mathrm{NH})$, 3062 (CH-aromatic), 2931-2854 (CH-aliphatic), 2191 (CN), 1643 (C=0) $\mathrm{cm}^{-1} ;{ }^{1} \mathrm{H}-\mathrm{NMR}$ (DMSO-d 6 ) d = 0.86$\left.1.02\left(\mathrm{~m}, 4 \mathrm{H}, 2 \mathrm{CH}_{2}\right), 1.76\left(\mathrm{~s}, 2 \mathrm{H}, \mathrm{CH}_{2}\right)\right), 1.96(\mathrm{~s}, 1 \mathrm{H}, \mathrm{CH}$-pyridine $), 2.00-2.94\left(\mathrm{~m}, 4 \mathrm{H}, 2 \mathrm{CH}_{2}\right), 6.70-8.71(\mathrm{~m}, 11 \mathrm{H}$, aromatic $\mathrm{H}), 9.23(\mathrm{~s}, 1 \mathrm{H}, \mathrm{OH})$ ), $9.87(\mathrm{~s}, 1 \mathrm{H}, \mathrm{NH}) ; \mathrm{MS}: \mathrm{m} / \mathrm{z}(\%) 454\left(\mathrm{M}^{+}+2\right)$. Anal. calcd for $\mathrm{C}_{28} \mathrm{H}_{24} \mathrm{~N}_{2} \mathrm{O}_{2} \mathrm{~S}(452)$ : C, 74.31; H, 5.35; N,6.19\%; Found:C, 74.33; H, 5.37; N,6.21\%.

General procedure for preparation of compounds (51a-c): A cold suspension of aryl diazonium salts $50 \mathrm{a}-\mathrm{c}$ $(0.02 \mathrm{~mol}$ ) (prepared from $0.02 \mathrm{~mol}$ of aromatic amine with the appropriate quantities of sodium nitrite and hydrochloric acid) was gradually added to a cold solution $\left(0-5^{\circ} \mathrm{C}\right)$ of $\mathbf{3}(0.002 \mathrm{~mol})$ in ethanol $(50 \mathrm{ml})$ containing anhydrous sodium acetate $(2 \mathrm{gm})$ with continuous stirring for $1 \mathrm{hr}$. The resulting reaction product was filtered off, washed with water and crystallized from the proper solvent to give compounds (51a-c).

1-(1-hydroxynaphthalen-2-yl)-2-(2-(4-methoxyphenyl)hydrazono)-3-phenyl propane-1,3-dione (51a): It was obtained as brown crystals from ethanol; yield (81\%); M.P.170-172 ${ }^{\circ} \mathrm{C}$; IR (KBr) n cm${ }^{-1}: 3420,3400(\mathrm{OH} / \mathrm{NH})$, 3062 (CH-aromatic), 2930 (CH-aliphatic), 1724, 1659 (2C=0) cm ${ }^{-1} ;{ }^{1} \mathrm{H}_{-} \mathrm{NMR}$ (DMSO-d ${ }_{6}$ ) d = $3.87\left(\mathrm{~s}, 3 \mathrm{H}, \mathrm{OCH}_{3}\right.$ ), 6.96-8.73 (m, 15H, aromatic H), $8.74(\mathrm{~s}, 1 \mathrm{H}, \mathrm{OH}), 11.00(\mathrm{~s}, 1 \mathrm{H}, \mathrm{NH}) ; \mathrm{MS}: \mathrm{m} / \mathrm{z}(\%) 424\left(\mathrm{M}^{+}\right)$. Anal. calcd for $\mathrm{C}_{26} \mathrm{H}_{20} \mathrm{~N}_{2} \mathrm{O}_{4}$ (424): $\mathrm{C}, 73.57 ; \mathrm{H}, 4.75 ; \mathrm{N}, 6.60 \%$; Found:C, 73.59; $\mathrm{H}, 4.77 ; \mathrm{N}, 6.62 \%$.

2-(2-(4-chlorophenyl)hydrazono)-1-(1-hydroxynaphthalen-2-yl)-3-phenylpropane-1,3-dione (51b): It was obtained as brown crystals from ethanol; yield (77\%); M.P.161-162 ${ }^{\circ} \mathrm{C}$; IR (KBr) n cm${ }^{-1}$ : 3449, $3419(\mathrm{OH} / \mathrm{NH})$, 3063 (CH-arom), 1723, $1650(2 \mathrm{C}=0) \mathrm{cm}^{-1} ;{ }^{1} \mathrm{H}-\mathrm{NMR}\left(\mathrm{DMSO}_{\mathrm{d}}\right) \mathrm{d}=7.23-8.71(\mathrm{~m}, 15 \mathrm{H}$, aromatic H), 8.72(s, $1 \mathrm{H}$, $\mathrm{OH})$ ), $12.00(\mathrm{~s}, 1 \mathrm{H}, \mathrm{NH}) ; \mathrm{MS}: \mathrm{m} / \mathrm{z}(\%) 430\left(\mathrm{M}^{+}+2\right)$. Anal. calcd for $\mathrm{C}_{25} \mathrm{H}_{17} \mathrm{ClN}_{2} \mathrm{O}_{3}(428): \mathrm{C}, 70.01 ; \mathrm{H}, 4.00 ; \mathrm{N}$, 6.53\%; Found:C, 70.02; $\mathrm{H}, 4.03 ; \mathrm{N}, 6.55 \%$.

1-(1-hydroxynaphthalen-2-yl)-3-phenyl-2-(2-p-tolylhydrazono) propane-1,3-dione (51c): It was obtained as brown crystals from ethanol; yield (71\%); M.P.166-168 ${ }^{\circ} \mathrm{C}$; IR (KBr) n cm${ }^{-1}: 3422,3400(\mathrm{OH} / \mathrm{NH}), 3063(\mathrm{CH}-$ aromatic), 2926 (CH-aliphatic), 1723, $1650(2 \mathrm{CO}) \mathrm{cm}^{-1} ;{ }^{1} \mathrm{H}-\mathrm{NMR}$ (DMSO-d $\left.\mathrm{d}_{6}\right) \mathrm{d}=1.91\left(\mathrm{~s}, 3 \mathrm{H}, \mathrm{CH}_{3}\right), 7.14-8.73$ $(\mathrm{m}, 15 \mathrm{H}$, aromatic $\mathrm{H}), 8.74(\mathrm{~s}, 1 \mathrm{H}, \mathrm{OH})), 12.00(\mathrm{~s}, 1 \mathrm{H}, \mathrm{NH})$; $\mathrm{MS}: \mathrm{m} / \mathrm{z}(\%) 408\left(\mathrm{M}^{+}\right)$. Anal. calcd for $\mathrm{C}_{26} \mathrm{H}_{20} \mathrm{~N}_{2} \mathrm{O}_{3}$ (408): C, 76.45; H, 4.94; N, 6.86\%; Found:C, 76.46; H, 4.96; N, $6.88 \%$.

General procedure for preparation of compounds (54a-c): A mixture of compounds 51a-c (0.001 mole), ammonium acetate $(3 \mathrm{gm})$ and malononitrile $(0.001 \mathrm{~mole})$ were fused for $10 \mathrm{~min}$. The solid precipitate so formed was treated with ethanol and filtered out and crystallized from the proper solvent to give (54a-c).

6-(1-hydroxy-2-naphthoyl)-3-imino-2-(4-methoxyphenyl)-5-phenyl-2,3-dihydropyridazine-4-carbonitrile (54a): It was obtained as brown crystals from dioxane; yield (79\%); M.P. $230-232{ }^{\circ} \mathrm{C}$; IR (KBr) n cm${ }^{-1}: 3421,3400$ $(\mathrm{OH} / \mathrm{NH}), 3065$ (CH-aromatic), 2928 (CH-aliphatic), $2200(\mathrm{CN}), 1650(\mathrm{C}=0) \mathrm{cm}^{-1} ;{ }^{1} \mathrm{H}-\mathrm{NMR}\left(\mathrm{DMSO}_{6} \mathrm{~d}_{6}\right) \mathrm{d}=3.99$ $\left(\mathrm{s}, 3 \mathrm{H}, \mathrm{OCH}_{3}\right), 6.68-8.25(\mathrm{~m}, 16 \mathrm{H}$, aromatic $\mathrm{H}$ and $\mathrm{NH}), 8.71(\mathrm{~s}, 1 \mathrm{H}, \mathrm{OH}) ; \mathrm{MS}: \mathrm{m} / \mathrm{z}(\%) 472\left(\mathrm{M}^{+}\right)$. Anal. calcd for $\mathrm{C}_{29} \mathrm{H}_{20} \mathrm{~N}_{4} \mathrm{O}_{3}$ (472): C, 73.72; $\mathrm{H}, 4.27 ; \mathrm{N}, 11.86 \%$; Found:C, 73.75; $\mathrm{H}, 4.29 ; \mathrm{N}, 11.88 \%$. 
2-(4-chlorophenyl)-6-(1-hydroxy-2-naphthoyl)-3-imino-5-phenyl-2,3-dihydropyridazine-4-carbonitrile (54b): It was obtained as brown crystals from dioxane; yield (79\%); M.P.258-260 ${ }^{\circ} \mathrm{C}$; IR (KBr) n cm${ }^{-1}: 3406,3400$ (OH/NH), 3063 (CH-aromatic), 2200 (CN), $1650(\mathrm{C}=0) \mathrm{cm}^{-1} ;{ }^{1} \mathrm{H}-\mathrm{NMR}$ (DMSO-d $\left.\mathrm{d}_{6}\right) \mathrm{d}=6.67-8.25(\mathrm{~m}, 16 \mathrm{H}$, aromatic $\mathrm{H}$ and $\mathrm{NH}), 8.71(\mathrm{~s}, 1 \mathrm{H}, \mathrm{OH}) ; \mathrm{MS}: \mathrm{m} / \mathrm{z}(\%) 478\left(\mathrm{M}^{+}+2\right)$. Anal. calcd for $\mathrm{C}_{28} \mathrm{H}_{17} \mathrm{ClN}_{4} \mathrm{O}_{2}$ (476): $\mathrm{C}, 70.52$; H, 3.59; N, 11.75\%; Found: C, 70.55; H, 3.63; N, 11.78\%.

6-(1-hydroxy-2-naphthoyl)-3-imino-5-phenyl-2-p-tolyl-2,3-dihydropyridazine-4-carbonitrile (54c): It was obtained as brown crystals from dioxane; yield (79\%); M.P.272-274 ${ }^{\circ} \mathrm{C} ; \mathrm{IR}(\mathrm{KBr}) \mathrm{n} \mathrm{cm}^{-1}: 3400,3385(\mathrm{OH} / \mathrm{NH})$, 3062 (CH-aromatic), 2963 (CH-aliphatic), 2202 (CN), 1650 (C=0) cm ${ }^{-1} ;{ }^{1} \mathrm{H}-\mathrm{NMR}$ (DMSO-d $\mathrm{d}_{6}$ ) d = 1.76 (s, 3H, $\left.\mathrm{CH}_{3}\right), 6.67-8.27(\mathrm{~m}, 16 \mathrm{H}$, aromatic $\mathrm{H}$ and $\mathrm{NH}), 8.72(\mathrm{~s}, 1 \mathrm{H}, \mathrm{OH}) ; \mathrm{MS}: \mathrm{m} / \mathrm{z}(\%) 457\left(\mathrm{M}^{+}+1\right)$. Anal. calcd for $\mathrm{C}_{29} \mathrm{H}_{20} \mathrm{~N}_{4} \mathrm{O}_{2}$ (456): C, 76.30; $\mathrm{H}, 4.42 ; \mathrm{N}, 12.27 \%$; Found: C, 76.33; $\mathrm{H}, 4.45 ; \mathrm{N}, 12.30 \%$.

\section{Conclusion}

In conclusion, compounds 3 and 5 were used as efficient precursors for the synthesis of new heterocycles including a-naphthol moiety with expected biological activities.

\section{Declarations}

\section{Author's contributions}

MAMA, SMB were responsible for the organic synthesis, and characterization experiments and department of Pharmacology, Faculty of Pharmacy, Mansoura University, Egypt for performing the antimicrobial evaluation. All authors read and +approved the final manuscript.

\section{Author details}

Department of Chemistry, Faculty of Science, Arish University, Arish 45511, Egypt.

\section{Acknowledgment}

The authors are very grateful to Prof. Dr. A. E. Khodair, Department of Chemistry, Faculty of Science, Suez Canal University, Ismailia, Egypt, for valuable support and reviewing this manuscript, and the authors are very grateful to Department of Microbiology, Faculty of Science, Arish University, Arish, Egypt for performing the antimicrobial evaluation.

\section{Availability of data and material}

The authors have the samples

\section{Funding}

Waiver 


\section{Competing interests}

The authors declare that they have no competing interests.

\section{Ethics approval and consent to participate}

All authors declare that they have ethics approval and consent to participate

\section{Consent for publication}

All authors consent to the publication

\section{Publisher's Note}

Springer Nature remains neutral with regard to jurisdictional claims in published maps and institutional affiliations.

\section{References}

1. Chauhan A, Sharma PK, Kaushk N (2011) Pyrazole: A Versatile Moiety. International Journal of ChemTech. Research 3 (1): 11-17

2. Sid A, Ziani N, Demmen-Debbih O, Mokhtari M, Lamara K (2013) Synthesis, characterization and antimicrobial evaluation of 1-((5,3-diaryl)-4,5-dihydro-1H-pyrazol-1-yl)propan-1-one. European Journal of chemistry 4(3): 268-271

3. Rostom SAF (2013) Polysubtituted pyrazoles, part 6. Synthesis of some 1-(4-chlorophenyl)-4-hydroxy1H-pyrazole-3-carbonyl derivatives linked to nitrogenous heterocyclic ring system as potential antitumor agents. Bioorganic \& Medicinal Chemistry 18: 2767-2776

4. Kumar KA, Jayaroopa P (2013) Pyrazoles: synthetic strategies and their pharmaceutical applications-An overview. International Journal of Pharm Tech Reseach 5(4): 1473-1486

5. Mistry BD, Desai BD, Patel JA, Patel NI (2012) Conventional and microwave-assisted synthesis of pyrazole derivatives and screening of their antibacterial and antifungal activities. Indian Journal of Chemistry 51(B): 746-751

6. Manikannan R, Venkatesan R, Muthusubramanian S, Yogeeswari P, Sriram D (2010) Pyrazole derivaitves from azines of substituted phenacyl aryl/cyclohexyl sulfides and their antimycobacterial activity. Bioorganic \& Medicinal Chemistry Letters 20: 6920-6924

7. Prasad YR, Rao AL, Prasoona L, Murali k, Kumar PR (2005) Synthesis and antidepressant activity of some 1,3,5-tripheny-2-pyrazolines and 3-(2ไ-hydrox;ynaphthalen-1 \-yl)-1,5-diphenyl-2-pyrazolines. Bioorganic \& Medicinal Chemistry Letters 15: 5030-3034

8. Ozdemir Z, Kandilci HB, Gumusel B, Calis U, Bilgin AA (2007) Synthesis and studies on antidepressant and anticonvulsant activities of some 3-(2-furyl)-pyrazoline derivatives. European Journal of Medicinal Chemistry 42: 373-379 
9. Abbas I, Gomha S, Elaasser M, Bauomi M (2015) Synthesis and biological evaluation of new pyridines containing imidazole moiety as antimicrobial and anticancer agents. Turk J Chem, 39: 334-346

10. Ghorab MM, Abdel-Hamide SG, Abou Zeid MM (1996) Synthesis of some new thiadiazole, eelena, triazine, thiazole and cyanopyridine derivatives with asssay for their antitumor activity. Phosphorus, Sulfer and Silicon Related Elem 112: 7-1

11. Malladi SH, Isloor AM, Peethambar SK, Ganesh BM, Goud PS (2012) Synthesis and antimicrobial activity of some new pyrazole containing cyanopyridone derivatives. Der Pharma Chemica 4(1): 43-52

12. Paghdar DJ, Akabari JD, Tala SD, Dhaduk MF, Joshi HS (2007) Synthesis of some new thiopyrimidine and oxopyrimidine heterocycles bearing 4-(methylsulfonyl)phenyl nucleus as potent antitubercular and antimicrobial agents. Indian Journal of. Heterocyclic. Chemmistry, 17: 113-116

13. El-Agrody AM, Abd El- Latif MS, El-Hady NA, Fakery AH, Bedair AH (2001) Heteroaromatization with 4hydroxycoumarin part II: synthesis of some new pyrano[2,3-d]pyrimidines, $[1,2,4]$ triazolo[1,5c]pyrimidines and pyrimido[1,6-b]-[1,2,4]triazine derivatives. Molecules 6: 519-527

14. Bedair AH, El-Hady NA, Abd El-Latif MS, Fakery AH, El-Agrody AM (2000) 4-Hydroxycoumarin in heterocyclic synthesis Part III. Synthesis of some new pyrano[2,3-d]pyrimidine, 2substituted[1,2,4]triazole[1,5-c]pyrimidine and pyrimido[1,6-b][1,2,4]triazine derivatives. Farmaco 55: 708714

15. El-Agrody AM, El-Hakim MH, Abd El-Latif MS, Fakery AH, El-Sayed EM, El- Ghareab KA (2000) Synthesis of pyrano[2,3-d]pyrimidine and pyrano[3,2-e]-[1,2,4]triazolo[2,3-c]pyrimidine derivatives with promising antibacterial activity. Acta Pharm, 50: 111-120

16. Taylor NR, Cleasby A, Singh O, Skarzynski T, Wonacott AJ, Smith PW, Sollis SL, Howes PD, Cherry PC, Bethell R, Colman P, Varghese J (1998) Dihydropyrancarboxamides related to zanamiver: A new series of inhibitors of influenza virus sialidases. 2.Crystallographic and molecular modeling study of complexes of 4-amino-4H-pyran-6-carboxamides and sialidase from influenza virus types A and B. J. Med. Chem 41: 798- 807

17. Hiramoto K, Nasuhara A, Michikoshi K, Kato T, Kikugawa K (1997) DNA strand-breaking activity and mutagenicity of 2,3-dihydro-3,5-dihydroxy-6-methyl-4H-pyran-4-one (DDMP), a Maillard reaction product of glucose and glycine. Mutation Research 395: 47-56

18. Martinez-Grau A, Marco JL (1997) Friedlander reaction on 2-amino-3-cyano-4H-pyrans: synthesis of derivaitives of $4 \mathrm{H}$-pyran [2,3-b] quinoline, new tacrine analogues. Bioorganic \&Medicinal Chemistry. Letters 7(24): 3165-3170

19. Wang D, Xie Y, Fan C, Yao SH, Song H (2014) efficient and mild cyclization procedures for the synthesis of novel 2-amino-4H-pyran derivatives with potential antitumor activity. Chinese Chemical Letters 25: 1011-1013

20. Thakur AS, Verma P, Chandy A (2010) A review on biological profile of pyridazinone containing drugs. Asian J. Research Chem. 3(2): 265- 271

21. Alam M, Zaman MS, Alam MM, Arora K, Ahmad A, Husain A (2015) Synthesis and antimicrobial activities of new pyrazolo-pyridazine derivatives. International Journal of Pharma Sciences and Research 6(03): 495-501 
22. El Ashry ESH, Kassem AA, Ramadan E (2006) Microwave irradiation for accelerating organic reactionsPart II: six-, seven-membered, spiro, and fused heterocycles. Adv. Heterocycl. Chem. 90: 1-123

23. El Ashry ESH, Awad LF, Ibrahim El, Bdeewy, OKH (2006) Microwave irradiation for accelerating the synthesis of acridine and xanthene derivatives from dimedone. ARKIVOC (ii): 178-186

24. Chauhan SS, Joshi YC (2008) Solid phase synthesis of isoxazole derivatives from diaryl 1,3-diketones under microwave irradiation. Rasayan J. Chem. 1(3): 475-480

25. Cirka V, Relich s (2011) microwave photochemistry. Applications in organic synthesis. Mini- Reviews in Organic Chemistry 8: 282-293

26. Ramiz MMM, Abdel Hafiz IS, Abdel Reheim MAM, Gaber HM (2012) Pyrazolones as building blocks in heterocyclic synthesis: synthesis of new pyrazolopyran, pyrazolopyridazine and pyrazole derivatives of expected antifungicidal activity. Journal of the Chinese Chemical Society 59: 72-80

27. Abdel Hafiz IS, Abdel Reheim MAM, Ramiz MMM (2014) Hydantion in heterocyclic synthesis: synthesis of new Imidazopyridine, Imidazotriazole, Pyrazolopurinone, Pyranoimidazole, Imidazopyridazine and Imidazopyrazole derivatives. J. Chem. Soc. Pak. 36 (5): 884-889

28. Reheim MAM, Abdel Hafiz IS, Elian MA (2016) A Simple and Convenient Synthesis of Isolated Fused Heterocycles Based on: 6-Phenyl-2-Thioxo-2,3-Dihydropyrimidin-4(5h)-One and 5-Acetyl-6-Phenyl-2Thioxo-2,3-Dihydropyrimidin-4(5h)-one. Heterocycles, 92(8): 1397-1414

29. Reheim MAM, Baker SM (2017) Synthesis, characterization and in vitro antimicrobial activity of novel fused pyrazolo[3,4-c]pyridazine, pyrazolo[3,4-d]pyrimidine, thieno[3,2-c]pyrazole and pyrazolo[3',4':4,5]thieno[2,3-d]pyrimidine derivatives. Chemistry Central Journal, 11:112

30. Reheim MAM, Abdel Hafiz IS, Mohamed S (2016) Utility of $\beta$-Diketones in heterocyclic synthesis: Synthesis of new tetrahydro-pyrimidinethione, pyrazole, thiophene, dihydropyridine, dihydropyrane, pyridazine derivatives and investigation of their antimicrobial activity. European Journal of Chemistry 7(3): 298-308

31. Kini SG, Choudhary S, Mubeen M (2012) synthesis, docking study and anticancer activity of coumarin substituted derivatives of benzothiazole. Journal of Computational Methods in Molecular Design 2(1): $51-60$

32. Garazd MM, Garazd YaL, Khilya VP (2005) Neoflavones.2.methods for synthesizing and modifying 4arylcoumarins. Chemistry of Natural Compounds 41(3): 245-271

33. Pandya AB, Prajapati DG, Pandya SS (2016) Synthesis of novel naphthalene COX inhibitors for antiinflammatory activity. Journal of Applied Pharmacetical Science 02(08): 226-232

34. Reheim MAM (2016) $\beta$-Ketoesters in Heterocylic Synthesis: Synthesis of new Dihydropyridine Tetrahydropyrimidine - Pyrazole Derivatives - Aminothiophene - Pyrazolopyrimidine. International Journal of Pharma Scinces 6(3): 1468-1479

35. Mohareb RM, Mohamed MH (2001) reaction of 2-amino-3-cyno-4,5,6,7-tetrahydrobenzo-[b]thiophene with ethyl acetoacetate: novel syntheses of pyridines, pyrazoles, and their fused derivatives. Heteroatom Chemistry 12(6): 518-527

36. Gein VL, Kazantseva MI, Kurbatova AA, Vahrin MI (2010) Synthesis of 4-aryl-2,7,7-trimethyl-5-oxo-Nphenyl-1,4,5,6,7,8-hexahydroquinoline-3-carboxamides. Chemistry of Heterocyclic Compounds 46(5): 
629-630

37. Gein VL, Kazantseva MI, Kurbatova AA (2011) Synthesis of 4,N-diaryl-2,7,7-trimethyl-5-oxo-1,4,5,6,7,8hexahydro-3-quinolinecarboxamides. Chemistry of Heterocyclic Compounds 47(6): 728-730

38. Gein VL, Kazantseva MI, Kurbatova AA (2011) Synthesis of 4,N-diaryl-2-methyl-5-oxo-1,4,5,6,7,8hexahydro-quinoline-3-carboxamides. Russian Journal of Organic Chemistry 47(6): 886-888

39. Hussein AM, Gad-Elkareem MAM, El-Adasy AAM, Othman IM (2009) N-1-napthyl-3-oxobutanamide in heterocyclic synthesis: a facile synthesis of nicotinamide, thieno[2,3-b]pyridine, and bi-or tricyclic annulated pyridine derivatives containing napthyl moiety. Phosphorus, Sulfer and Silicon 184: 22632280

40. Aly HM, Kamal MM (2012) Efficient one-pot preparation of novel fused chromeno[2,3-d]pyrimidine and pyrano[2,3-d]pyrimidine derivatives. European Journal of Medicinal Chemistry 47: 18-23

41. Dyachenko AD, Desenko SM, Dyachenko VD, Rusanov EB (2003) Synthesis and crystal structure of 3carbamoyl-6-methyl-5-phenyl-carbamoyl-2-thioxo-1,2,3,4-tetrahydropyridine-4-spirocyclohexane. Chem. Heterocycl. Compounds 39(6): 744-748

42. Othman IMM, Nasr HM, Hassan MI (2014) Synthesis of some novel pyridazine, thienopyridazine, pyrazolopyridine, pyridopyrazolopyrimidine and pyridopyrazolotriazine derivatives with their antimicrobial activity. Canadian Chemical Transactions 2: 504-517

43. Murray PR, Baron EJ, Pfaller MA, Tenover FC,Yolken RH, in: GL wood, JA Washington (Eds.), Manual of Clinical Microbiology, Am. Soc. Microbiol., Washington, DC, 1995.

44. Jones RN, Barry AL,Gavan TL, Washington, I. I. A, in: EH Lennette, A Ballows, WJ HauslerJr, HJ Shadomy (Eds.), Manual of Clinical Microbiology, fourth edn, Am. Soc. Microbiol. (1972), Washington DC, 1985.

\section{Tables}

Table 1. Antibacterial and antifungal activities of synthesized compounds. 


\begin{tabular}{|c|c|c|c|c|c|c|c|c|c|c|c|c|}
\hline \multirow[t]{3}{*}{ Compound } & \multicolumn{4}{|c|}{ Gram Negative Bacteria (-ve) } & \multicolumn{4}{|c|}{ Gram Positive Bacteria (+ve) } & \multicolumn{4}{|c|}{ Fungal Species } \\
\hline & \multicolumn{2}{|c|}{ E. coli } & \multicolumn{2}{|c|}{$P$. aeuroginosa } & \multicolumn{2}{|c|}{ S. aureus } & \multicolumn{2}{|c|}{ B. subtilis } & \multicolumn{2}{|c|}{ C. albicans } & \multicolumn{2}{|c|}{ A. flavus } \\
\hline & $\begin{array}{l}\text { DIZ } \\
(\mathrm{mm})\end{array}$ & $\begin{array}{l}\% \\
\text { Activity } \\
\text { index }\end{array}$ & $\begin{array}{l}\text { DIZ } \\
(\mathrm{mm})\end{array}$ & $\begin{array}{l}\% \\
\text { Activity } \\
\text { index }\end{array}$ & $\begin{array}{l}\text { DIZ } \\
(\mathrm{mm})\end{array}$ & $\begin{array}{l}\% \\
\text { Activity } \\
\text { index }\end{array}$ & $\begin{array}{l}\text { DIZ } \\
(\mathrm{mm})\end{array}$ & $\begin{array}{l}\% \\
\text { Activity } \\
\text { index }\end{array}$ & $\begin{array}{l}\text { DIZ } \\
(\mathrm{mm})\end{array}$ & $\begin{array}{l}\% \\
\text { Activity } \\
\text { index }\end{array}$ & $\begin{array}{l}\text { DIZ } \\
(\mathrm{mm})\end{array}$ & $\begin{array}{l}\% \\
\text { Activity } \\
\text { index }\end{array}$ \\
\hline $35 \mathrm{c}$ & 4.1 & 13.7 & 9 & 33.5 & 13.4 & 52.1 & 12 & 45.6 & 13 & 44.6 & 15 & 57.0 \\
\hline $40 \mathrm{a}$ & 5.2 & 18.8 & 13 & 44.5 & 14.7 & 56.8 & 14.3 & 54.4 & 16.3 & 55.2 & 17.4 & 66.6 \\
\hline $51 \mathrm{a}$ & NA & - & NA & - & 10 & 39.6 & 8 & 32.4 & 13 & 45.7 & 14 & 49.2 \\
\hline 29 & 18.4 & 79.9 & 23 & 94.5 & 25 & 93.5 & 24.8 & 98.9 & 19.1 & 77.3 & 24 & 88.1 \\
\hline 10 & 15 & 64.6 & 17.5 & 70.9 & 22.5 & 86.3 & 19 & 87.9 & 19.3 & 73.8 & 24.8 & 83.7 \\
\hline $40 \mathrm{~b}$ & 3 & 10.5 & 7 & 23.8 & 5 & 14.7 & NA & - & 4 & 13.5 & 6 & 24.0 \\
\hline 14 & 8 & 29.6 & 10 & 48.7 & 9 & 26.7 & 6 & 18.9 & 8 & 25.2 & 13 & 43.4 \\
\hline $16 a$ & 14.3 & 54.5 & 15 & 66.7 & 16.7 & 80.0 & 19.6 & 85.6 & 19 & 59.7 & 17.8 & 69.1 \\
\hline 3 & 9 & 37.8 & 19 & 61.5 & 14 & 46.3 & 11 & 36.8 & 11 & 22.8 & 10 & 33.0 \\
\hline $35 a$ & 15 & 70.0 & 20 & 83.9 & 19.7 & 73.8 & 19.6 & 77.3 & 17.6 & 63.5 & 19.4 & 73.6 \\
\hline $35 \mathrm{~b}$ & 11 & 40.8 & 17.3 & 63.9 & 16.9 & 71.7 & 17.8 & 69.4 & 12.9 & 56.0 & 18 & 62.0 \\
\hline 23 & NA & - & 4 & 13.8 & 3 & 8.9 & NA & - & 5 & 12.3 & 7 & 17.0 \\
\hline 26 & 13 & 49.5 & 16 & 69.2 & 14 & 65.5 & 14 & 58.5 & 10 & 25.6 & 14 & 42.0 \\
\hline $45 \mathrm{c}$ & NA & - & NA & - & $\mathrm{NA}$ & - & NA & - & NA & - & NA & 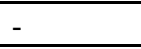 \\
\hline $49 a$ & 5 & 24.8 & 12 & 54.2 & 8 & 35.3 & 6 & 21.7 & 8 & 33.3 & 11 & 44.0 \\
\hline 5 & NA & - & NA & - & NA & - & NA & - & NA & - & NA & - \\
\hline $54 a$ & 11 & 77.2 & 27 & 83.9 & 24 & 84.5 & 31 & 97.6 & 24.7 & 85.3 & 28.5 & 97.0 \\
\hline Ampicillin & 25 & 100 & 25 & 100 & 24 & 100 & 25 & 100 & NA & - & NA & - \\
\hline Clotrimazole & NA & - & NA & - & $\mathrm{NA}$ & - & NA & - & 26 & 100 & 26 & 100 \\
\hline
\end{tabular}

NA: No activity; DIZ, Diameter of inhibition zone.

Table 2. Minimum inhibitory concentrations (MIC) for selected compounds.

\begin{tabular}{|c|c|c|c|c|c|c|}
\hline \multirow[t]{2}{*}{ Compounds } & \multicolumn{6}{|c|}{ Minimum Inhibitory Concentration (MIC) of the synthesized compounds $(\mu \mathrm{g} / \mathrm{mL}$ ) } \\
\hline & E. coli & P. aeuroginosa & S. aureus & B. subtilis & C. albicans & A. flavus \\
\hline $35 \mathrm{c}$ & 760 & 530 & 270 & 500 & 65.5 & 50.9 \\
\hline $40 \mathrm{a}$ & 780 & 385 & 260 & 500 & 48.9 & 29.4 \\
\hline $51 \mathrm{a}$ & NA & NA & 530 & 740 & 95.7 & 69.5 \\
\hline 29 & 98.7 & 68.5 & 66.5 & 135 & 14.6 & 8.8 \\
\hline 10 & 197.5 & 135 & 90.7 & 189.4 & 22.4 & 9.8 \\
\hline $40 \mathrm{~b}$ & NA & 750 & NA & NA & 510 & 365 \\
\hline 14 & 540 & 260 & 740 & NA & 188.5 & 93.7 \\
\hline $16 a$ & 188.4 & 125 & 125 & 177.5 & 37.2 & 17.6 \\
\hline 3 & 385 & 187.5 & 375 & 740 & 260 & 187.5 \\
\hline $35 a$ & 145 & 92.7 & 135.7 & 240 & 24.4 & 14.7 \\
\hline $35 b$ & 365 & 197.5 & 177.9 & 240 & 63.5 & 39.2 \\
\hline 23 & NA & NA & NA & NA & 760 & 600 \\
\hline 26 & 240 & 136 & 187.8 & 385 & 260 & 145 \\
\hline $45 \mathrm{c}$ & NA & NA & NA & NA & NA & NA \\
\hline $49 a$ & 520 & 260 & 500 & NA & 125 & 97.7 \\
\hline 5 & NA & NA & NA & NA & NA & NA \\
\hline $54 a$ & 125 & 93.7 & 93.7 & 125 & 11.7 & 3.9 \\
\hline Ampicillin & 125 & 187.5 & 93.7 & 187.5 & NA & NA \\
\hline Clotrimazole & NA & $\mathrm{NA}$ & NA & NA & 7.8 & 5.8 \\
\hline
\end{tabular}

NA: No activity. 
This is a list of supplementary files associated with this preprint. Click to download.

- scheme.doc

- formula1.JPG 